\title{
EFFECT OF TUNICAMYCIN ON THE SYNTHESIS OF MACROMOLECULES IN CULTURES OF CHICK EMBRYO FIBROBLASTS INFECTED WITH NEWCASTLE DISEASE VIRUS
}

\author{
Akira Takatsuki and Gakuzo Tamura \\ Laboratory of Microbiology, Department of Agricultural Chemistry, \\ The University of Tokyo, Bunkyo-ku, Tokyo, Japan
}

(Received for publication May 24, 1971)

\begin{abstract}
The effect of tunicamycin on the synthesis of macromolecules in cultures of chick embryo fibroblasts was investigated by measuring the incorporation of radioactive percursors into acid-insoluble product after infection or mockinfection with Newcastle disease virus (NDV). Tunicamycin had slight or no effect on incorporation of uridine, thymidine and choline. Protein synthesis proceeded to some extent depending on concentrations of tunicamycin. Incorporation of glucosamine and glucose was greatly affected by the antibiotic at low concentrations. Mechanism of action of tunicamycin against NDV multiplication is discussed in relation to membrane synthesis.
\end{abstract}

Tunicamycin is a potent antiviral antibiotic containing glucosamine ${ }^{1)}$. It inhibits multiplication of NDV when it is added during viral one-step growth cycle ${ }^{2)}$, and the antiviral activity is partially reversed by some aminosugar derivatives. ${ }^{3)}$ Tunicamycin has also antimicrobial activity and induces various morphological changes in microorganisms. ${ }^{4}$ The effect of tunicamycin on the synthesis of macromolecules has been studied using cultures of chick embryo fibroblasts (CEF) infected or mock-infected with NDV as the first step in elucidation of the action mechanism of the antibiotic on NDV multiplication.

\section{Materials and Methods}

Virus and cell culture: The Miyadera strain of NDV and primary monolayer cultures of CEF were employed. Preparative methods were the same as reported previously. ${ }^{5}$

Effect of tunicamycin on the synthesis of macromolecules: Macromolecular synthesis in cultures of $\mathrm{CEF}$ was followed by incorporation of radioactive precursors into acidinsoluble product. Duplicate samples were treated with tunicamycin and, at designated time intervals, chilled in melting ice to stop incorporation of radioactive compounds. Sufficient $50 \%$ trichloroacetic acid (TCA) was added to make the samples $10 \%$ in respect to TCA after freezing-and-thawing three to five times in a dry ice-acetone bath. The samples were stored in an ice-water bath for more than 3 hours. Cold TCA-insoluble precipitates were then collected on Millipore filters and washed three times with cold $10 \%$ TCA $(2 \mathrm{ml}$ each). The filters were placed into glass scintillation vials and dried at $80^{\circ} \mathrm{C}$. Ten milliliters of scintillation liquid containing $6 \mathrm{~g}$ PPO and $0.4 \mathrm{~g}$ dimethylPOPOP per $1,000 \mathrm{ml}$ toluene were added to each vial. Radioactivity was counted using a liquid scintillation counter (Hitachi-Horiba, Tokyo). Some modifications of the methods will be described in the text or legends. 
Sucrose density-gradients centrifugation: Ribonucleic acid (RNA) was extracted by the sodium dodecyl sulfate (SDS)-phenol method and precipitated with three volumes of ethanol at $-20^{\circ} \mathrm{C}$ as described previously. ${ }^{5)}$ Precipitates were collected by centrifugation, redissolved in phosphate buffered $(0.05 \mathrm{M}, \mathrm{pH} 6.7)$ saline $(0.1 \mathrm{M})$, and loaded on preformed sucrose density-gradients $(5 \sim 15 \mathrm{w} / \mathrm{v} \%, 4.5 \mathrm{ml}$ per tube) containing the same buffer. After a 6 hour-run in a swinging bucket rotor (RPS 40) at $130,000 \times g$ using a preparative ultracentrifuge Model 65P, Hitachi, fractionation was carried out drop-wise by puncturing the bottom of the tubes. Bovine serum albumin $(200 \mu \mathrm{g})$ was added to each fraction ( $c a$. $0.15 \mathrm{ml}$ ) and cold $10 \%$ TCA-insoluble radioactivity was counted as described above.

Chemicals: Tunicamycin was prepared according to the method reported previously). and the same lot of the antibiotic was used throughout these experiments. Uridine $-{ }^{14} \mathrm{C}$ (uniformly labeled; specific activity, $492 \mathrm{mCi} / \mathrm{mM}$ ), uridine $-5{ }^{-3} \mathrm{H}$ (specific activity, $5.0 \mathrm{Ci} /$ $\mathrm{mM}$ ), thymidine-6- ${ }^{3} \mathrm{H}$ (specific activity, $25.3 \mathrm{Ci} / \mathrm{mM}$ ), choline chloride-methyl- ${ }^{14} \mathrm{C}$ (specific activity, $54 \mathrm{mCi} / \mathrm{mM}$ ), D-glucose ${ }^{14} \mathrm{C}$ (uniformly labeled; specific activity, $261 \mathrm{mCi} / \mathrm{mm}$ ), Dglucosamine $-1-{ }^{14} \mathrm{C}$ (specific activity, $55.6 \mathrm{mCi} / \mathrm{mM}$ ) and carrier-free ${ }^{32} \mathrm{P}$ were purchased from the Radiochemical Centre, Amersham, England. ${ }^{14} \mathrm{C}-\mathrm{Amino}$ acids mixture was obtained from Dai-Ichi Chemicals, Tokyo, Japan. Actinomycin D was a gift from Merck, Sharp and Dohme International, New York, U.S.A.

\section{Results}

\section{Effect on Synthesis of NDV- and CEF-RNA}

Monolayer cultures of CEF in test tubes were infected or mock-infected with NDV at an input multiplicity of 10 plaque-forming units (PFU) per cell. Actinomycin D $(5.0 \mu \mathrm{g} / \mathrm{ml})$ was added to stop cellular DNA-dependent RNA synthesis after 5-hour incubation of infected cells at $39^{\circ} \mathrm{C}$, and cell sheets were re-fed with fresh medium

Fig. 1. Anti-NDV-activity of tunicamycin added at various times after the infection.

Monolayer cultures of CEF in test tubes $(1 \mathrm{ml}$ / tube) were infected with NDV at an input multiplicity of $10 \mathrm{PFU}$ per cell. Tunicamycin $(0.5 \mu \mathrm{g} / \mathrm{ml})$ was added at various times after the infection, and effect of the antibiotic on virus multiplication was followed by titration of hemagglutinin. The titration method was the same as repoted previously, ${ }^{5)}$ and virus production was expressed as hemagglutinin units (H.AU) per $\mathrm{ml}$

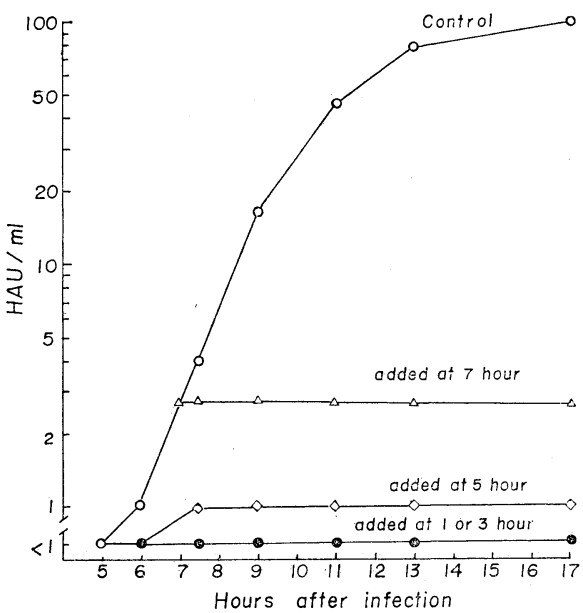

Fig. 2. Effect of tunicamycin on NDV- and CEF-RNA synthesis.

RNA synthesis in NDV-infected (10 PFU/cell) and mock-infected cultures of $\mathrm{CEF}$ in test tubes $(1 \mathrm{ml} / \mathrm{tube})$ was assessed by the incorporation of ${ }^{14} \mathrm{C}$-uridine $(0.5 \mu \mathrm{Ci} / \mathrm{ml})$ into acid-insoluble product. NDV-RNA synthesis(A) was revealed by the inhibition of CEF-RNA by actinomycin D $(5.0 \mu \mathrm{g} / \mathrm{ml})$. CEF-RNA synthesis(B) in mock-infected cells was followed in the absence of actinomycin $\mathrm{D}$.
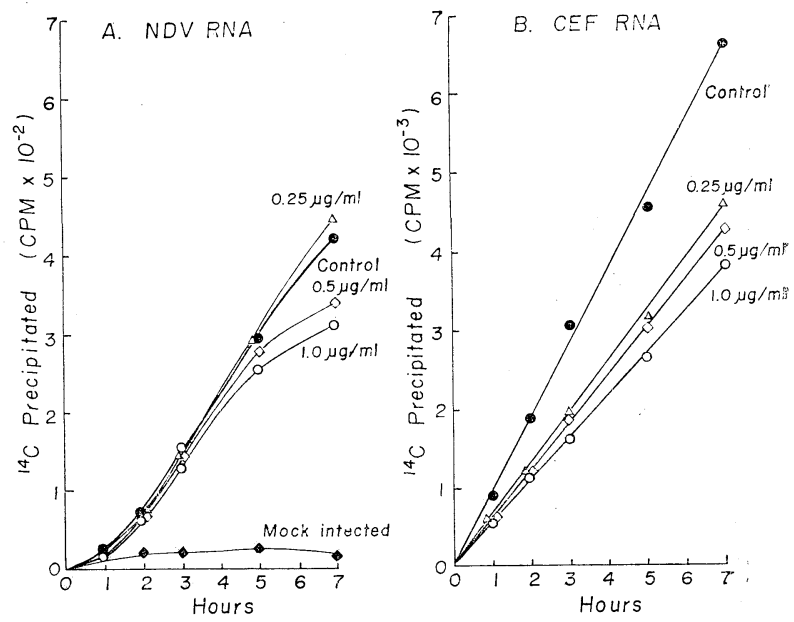
containing actinomycin D $(5.0 \mu \mathrm{g} / \mathrm{ml}),{ }^{14} \mathrm{C}-U$ ridine $(0.5 \mu \mathrm{Ci} / \mathrm{ml})$ and tunicamycin at 1 hour after the addition of actinomycin D, when CEF-RNA was nearly completely suppressed (Fig. 2 A, mock-infected).

NDV multiplication was inhibited immediately on addition of tunicamycin $(0.5$ $\mu \mathrm{g} / \mathrm{ml}$ ). whenever the antibiotic was added during the viral multiplication cycle as revealed by titration of hemagglutinin (Fig. 1). But viral RNA synthesis proceeded normally or was affected slightly in the presence of tunicamycin (Fig. 2 A).

CEF-RNA synthesis was affected slightly by tunicamycin and proceeded at a constant rate for a prolonged time (Fig. 2 B).

NDV-RNA labeled with ${ }^{14} \mathrm{C}$-uridine was separated by centrifugation $(10,000 \times g$,

Fig. 3. Synthesis and RNase-resistance of NDV-RNA

Cultures of CEF in test tubes ( $1 \mathrm{ml} / \mathrm{tube}$ ) were infected with NDV (10 PFU/cell) and treated with actinomycin $\mathrm{D}(5.0 \mu \mathrm{g} / \mathrm{ml})$ at 5 hours after the infection. Infected cultures were re-fed with prewarmed fresh medium containing actinomycin $\mathrm{D}(5.0 \mu \mathrm{g} / \mathrm{ml})$ and ${ }^{14} \mathrm{C}$-uridine $(0.5 \mu \mathrm{Ci} / \mathrm{ml})$ at 6 hours after the infection. Tunicamycin was added at the same time with the radioactive uridine. At designated time intervals duplicate samples were chilled in an ice-water bath. After freezing-and-thawing four times destructed cell debris were separated into soluble and particulate fractions by centrifugation $(10,000 \times g$, 15 minutes), and each was divided into two fractions. One was treated with RNase $\left(100 \mu \mathrm{g} / \mathrm{ml}, 37^{\circ} \mathrm{C}, 30\right.$ minutes) and precipitated with TCA, and the other was precipitated with TCA without RNase-treatment. Total radioactivity in particulate (A) and cytoplasmic (B) fractions and RNase-resistant radioactivity in both fractions $\left(A^{\prime}\right.$ and $B^{\prime}$ ) were counted as described in Materials and Methods.

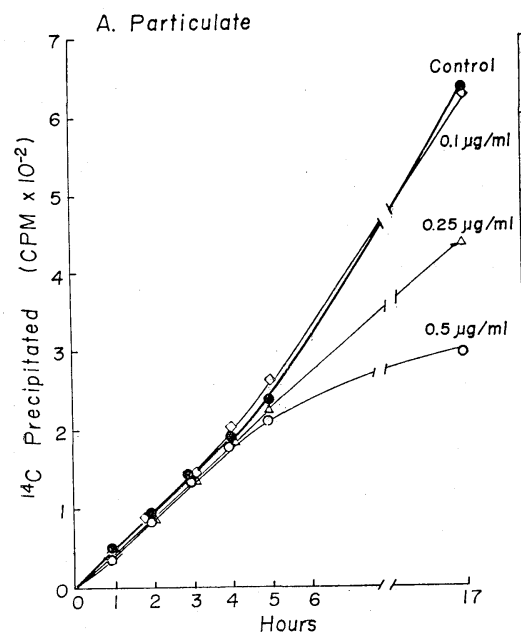

B. Cytoplasmic
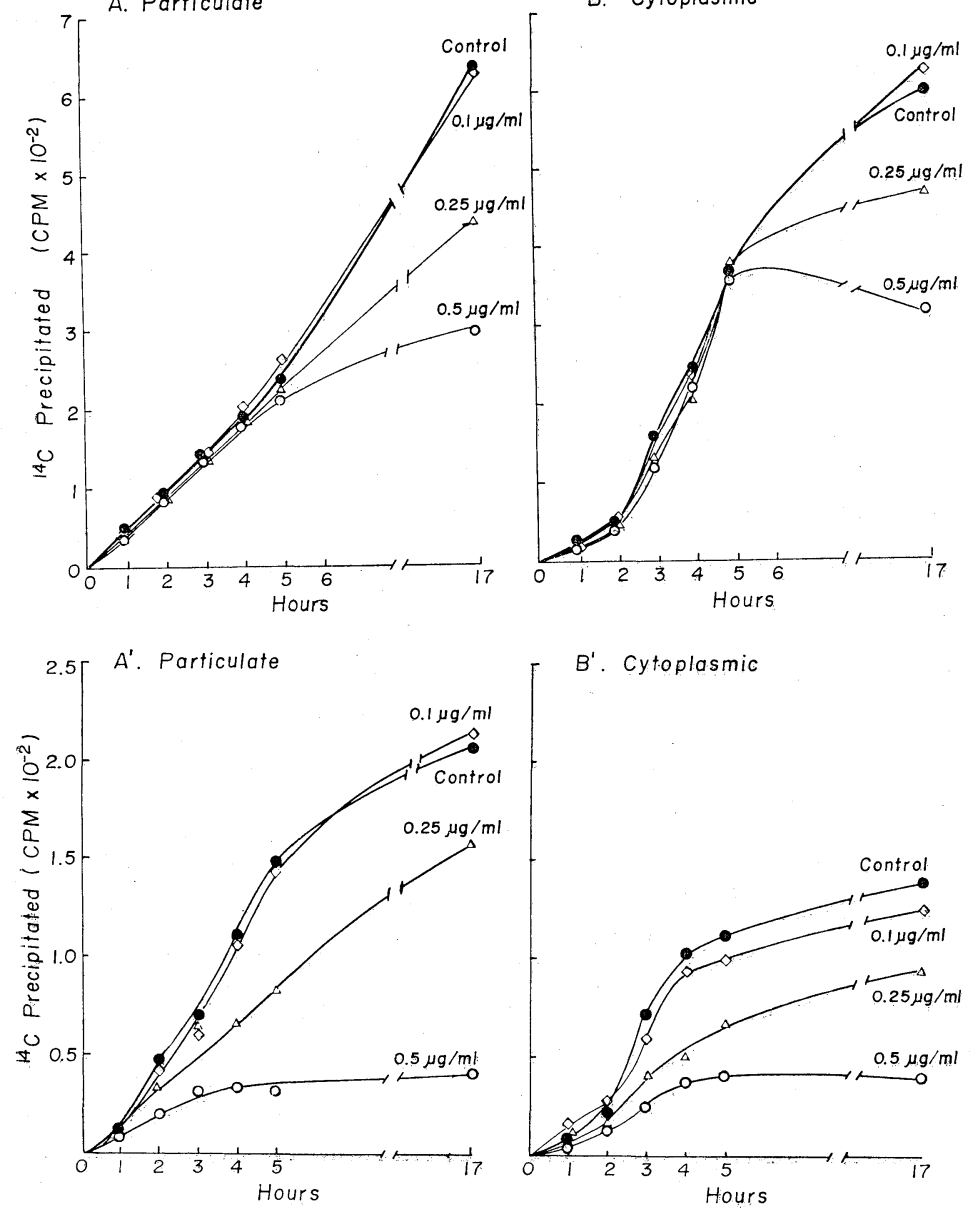
15 minutes) into two fractions, i.e., membrane-bound and cytoplasmic, after freezing-and-thawing four times. Each fraction was divided into two portions. One was treated with $100 \mu \mathrm{g} / \mathrm{ml}$ ribonuclease A (RNase) for 30 minutes at $37^{\circ} \mathrm{C}$ and added to cold TCA, and the other was added to TCA without treatment. Membranebound and cytoplasmic NDV-RNA were synthesized at nearly the same rate in the presence of tunicamycin $(0.1 \sim 0.5 \mu \mathrm{g} / \mathrm{ml})$ as in the controls for at least 5 hours (Fig. $3 \mathrm{~A}$ and B). A difference was detected in the rate of syntheses of membrane-bound and cytoplasmic NDV-RNA. Membrane-bound NDV-RNA synthesis increased linearly and cytoplasmic virus RNA exponentially. RNase treatment revealed significant differences in the state of newly synthesized NDV-RNA between tunicamycin-treated and control cultures (Fig. $3 \mathrm{~A}^{\prime}$ and $\mathrm{B}^{\prime}$ ). Total NDV-RNA synthesis proceeded to similar extents in the presence of tunicamycin as in the control for the first 5 hours (Fig. $3 \mathrm{~A}$ and B), but treatment with RNase solubilized NDV-RNA synthesized in the presence of tunicamycin more extensively than in the control, especially at a drug concentration of $0.5 \mu \mathrm{g} / \mathrm{ml}$. These results indicate that the NDV-RNA synthesized in the presence of tunicamycin is not associated with viral capsid protein or encapsulated incompletely at high drug concentrations. A preliminary experiment suggests the latter possibility applies (unpublished observation).

Extracted NDV-RNA labeled with ${ }^{3} \mathrm{H}$-uridine was analyzed by sucrose densitygradient centrifugation or methylated albumin-Kieselguhr (MAK) column chromatography. Profiles of the sucrose-density-gradients with NDV-RNA did not reveal significant differences between the control and tunicamycin-containing samples (Fig. 4), and similar results were obtained by MAK column chromatography (Fig. 5). These studies reflect the sum of viral RNA synthesized in infected cells, and analysis of the various fractions of NDV-RNA is now under study with fractionated viral 
Fig. 5. Effect of túnicamycin on NDV-RNA synthesis às analyzed by MAK column chromatography.

NDV-RNA was labeled and extracted according to the same method as Fig. 4 except 32P-phosphate $(50 \mu \mathrm{Ci} / \mathrm{ml})$ was used instead of ${ }^{3} \mathrm{H}$-uridine. Monolayer cultures of $\mathrm{CEF}$ in four Petri dishes were used for the preparation of RNA. A half of the RNA preparation $(1 \mathrm{ml})$ was loaded on MAK column $(25 \times$ $300 \mathrm{~mm}$ ). MAK column chromatography was carried out as described prevlously. ${ }^{5)}$

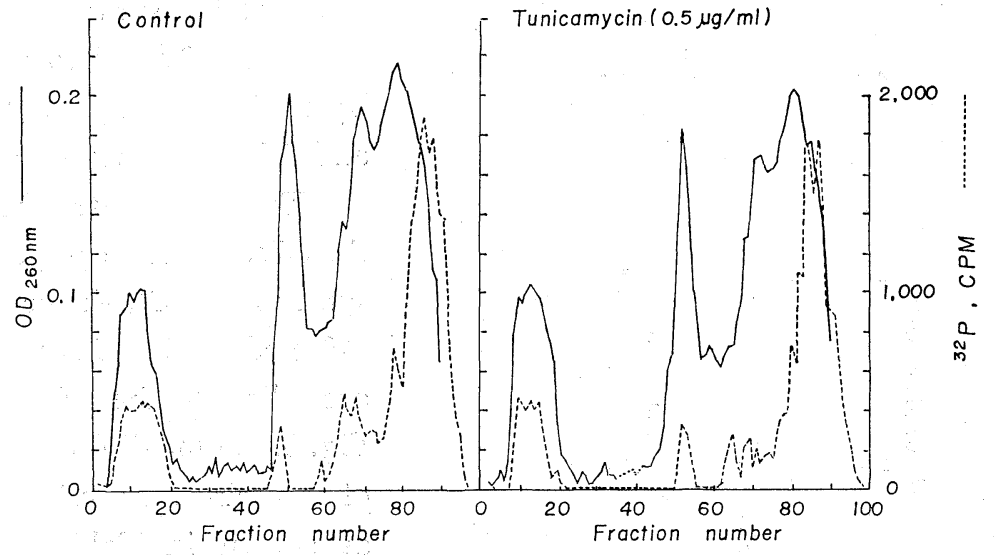

RNA, such as membrane-bound, cytoplasmic and capsid-associated RNA.

Analysis of CEF-RNA synthesized in the presence of tunicamycin by sucrose density-gradient centrifugation reveals some abnormalities. At 4 hour of treatment, significant difference was not detected in the sucrose density-gradient profiles between the control and tunicamycintreated samples (Fig. 6 A, B and $\mathrm{C}$ ). But at 24 hour of treatment the profiles reveal that RNA lost its native size and radioactive peaks were detected at lighter regions, and this tendency was more significant at a drug concentration of $-0.5 \mu \mathrm{g} / \mathrm{ml}$ than at $0.25 \mu \mathrm{g} / \mathrm{ml}$ (Fig. $6 \mathrm{D}, \mathrm{E}$ and F). Degradation of RNA in the presence of tunicamycin was observed with Bacillus subtilis. ${ }^{4} \quad$ Pulse-chase experiments are required for a precise analysis of the nature of the CEF-RNA degradation.

Fig. 6. Sucrose density-gradient profiles of CEF-RNA synthesized in the presence and absence of tunicamycin.

Monolayer cultures of CEF in Petri dishes $(9 \mathrm{~cm}$ in diameter, $15 \mathrm{ml} / \mathrm{dish}$ ) were re-fed with fresh medium ( $5 \mathrm{ml} /$ dish) containing ${ }^{3} \mathrm{H}$-uridine $(5 \mu \mathrm{Ci} / \mathrm{ml})$. Treatment with tunicamycin $(0.25$ or $0.5 \mu \mathrm{g} / \mathrm{ml})$ was started at the same time. After 4 (A, B and C) or 24 hours (D, E and $\mathrm{F}$ ) of incubation at $39^{\circ} \mathrm{C}$, RNA was extracted by the SDS-phenol method. Two dishes were used for each sample. Labeled RNA was analyzed by sucrose densitygradient $(5 \sim 15 \mathrm{w} / \mathrm{v} \%, 4.5 \mathrm{ml})$ centrifugation $(130,000 \times g$, 6 hours).

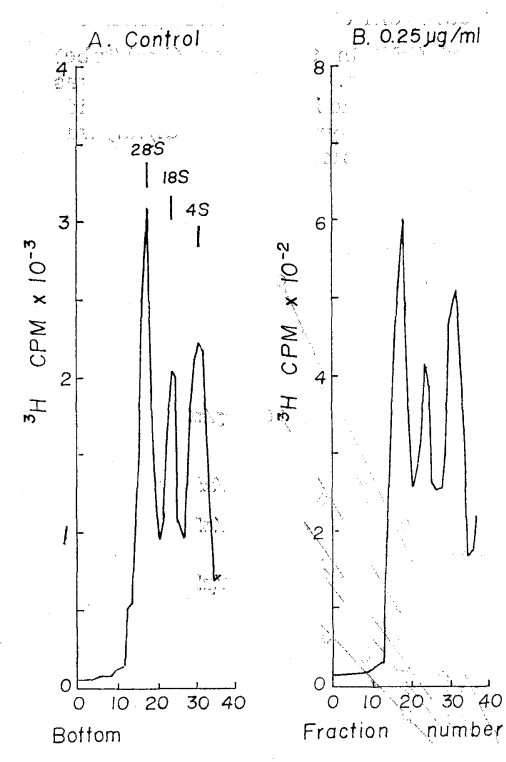
C. $0.5 \mu \mathrm{g} / \mathrm{ml}$

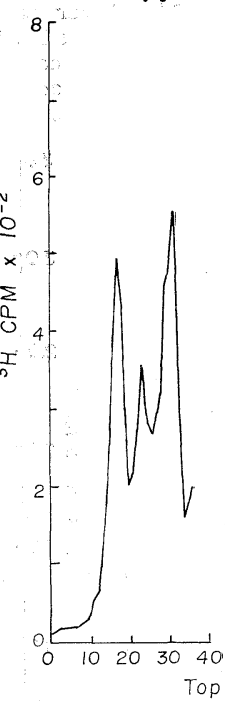

\section{Effect on GEF-DNA Synthesis}

Effect of tunicamycin on the synthesis of CEF-DNA was assessed by incorporation of ${ }^{3} \mathrm{H}$-thymidine into acid-insoluble product. Inhibition of the incorporation by 
Fig. 6 ,

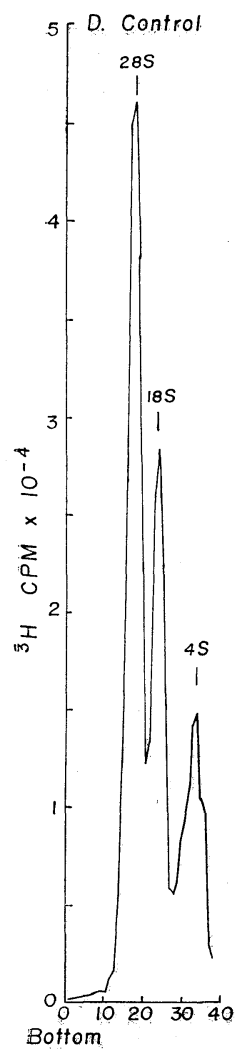

E. $0.25 \mu \mathrm{g} / \mathrm{ml} \quad$ F. $0.5 \mu \mathrm{g} / \mathrm{ml}$

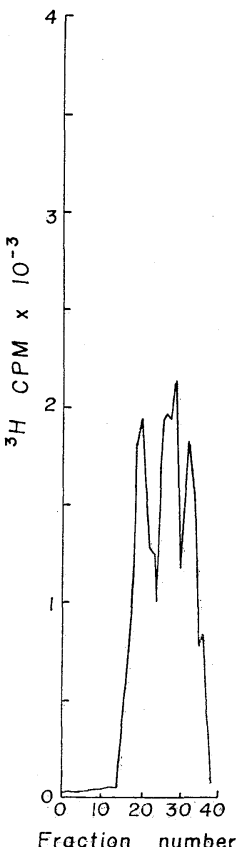

tunicamycin was significant only at high antibiotic concentration (Fig. 7).

3 Effect on Protein Synthesis

Protein synthesis in cultured CEF was affected to a large extent by tunicamycin than cellular RNA and DNA syntheses (Fig. 8).

To investigate the nature of the effect of tunicamycin on protein synthesis, NDV-infected or mockinfected CEF were fractionated according to the scheme shown in Fig. 9. Some differential inhibition of protein synthesis was detected as shown in Table 1. Membrane and extracellular secreted protein synthesis was more sensitive to tunicamycin inhibition than cytoplasmic protein synthesis in mockinfected CEF. Infection with NDV decreased amino acid incorporation into all fractions. Treatment of NDV-infected GEF with tunicamycin decreased incorporation to about $50 \%$ of the control as for cytoplasmic and secreted protein

Fig. 8. Effect of tunicamycin on protein synthesis.

${ }^{14} \mathrm{C}$-Amino acid mixture $(0.1 \mu \mathrm{Ci} / \mathrm{ml})$ was added to cultures of CEF in test tubes $(1 \mathrm{ml}$ / tube), and protein synthesis was assessed by counting acid-insoluble radioactivity.

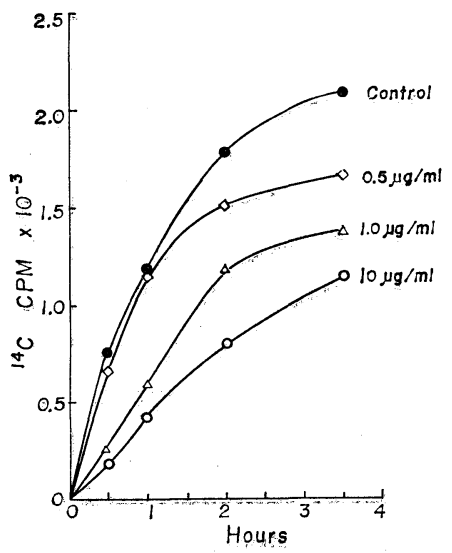


Table 1. Effect of tunicamycin on ${ }^{14} \mathrm{C}$-amino acids incorporation into cytoplasmic, membrane and secreted proteins

\begin{tabular}{|c|c|c|c|c|c|}
\hline \multirow{2}{*}{ Fractions } & \multirow{2}{*}{$\begin{array}{c}\text { NDV } \\
\text { infection }\end{array}$} & \multirow{2}{*}{$\begin{array}{c}\text { Tunicamycin } \\
(0.5 \mu \mathrm{g} / \mathrm{ml}) \\
\text { treatment }\end{array}$} & \multicolumn{3}{|c|}{ Radioactivity } \\
\hline & & & Total $\mathrm{CPM} \times 10^{-3}$ & & \\
\hline \multirow{2}{*}{ Cytoplasmic } & - & $\bar{t}$ & $\begin{array}{l}31.9 \\
21.1\end{array}$ & $\begin{array}{r}100 \\
68\end{array}$ & $\begin{array}{r}100 \\
68\end{array}$ \\
\hline & + & $\overline{+}$ & $\begin{array}{l}24.6 \\
11.9\end{array}$ & $\begin{array}{r}100 \\
49\end{array}$ & $\begin{array}{l}77 \\
37\end{array}$ \\
\hline \multirow{2}{*}{ Membrane } & - & $\bar{t}$ & $\begin{array}{l}38.2 \\
20.9\end{array}$ & $\begin{array}{r}100 \\
55\end{array}$ & $\begin{array}{r}100 \\
55\end{array}$ \\
\hline & + & $\bar{t}$ & $\begin{array}{l}30.2 \\
26.0\end{array}$ & $\begin{array}{r}100 \\
87\end{array}$ & $\begin{array}{l}79 \\
68\end{array}$ \\
\hline \multirow{2}{*}{ Secreted } & - & $\overline{+}$ & $\begin{array}{l}8.0 \\
4.8\end{array}$ & $\begin{array}{r}100 \\
60\end{array}$ & $\begin{array}{r}100 \\
60\end{array}$ \\
\hline & + & $\bar{t}$ & $\begin{array}{l}5.3 \\
3.0\end{array}$ & $\begin{array}{r}100 \\
57\end{array}$ & $\begin{array}{l}66 \\
38\end{array}$ \\
\hline
\end{tabular}

Monolayer cultures of CEF in test tubes were infected (10 PFU per cell) or mock-infected with NDV. After a 2-hour adsorption period at $4^{\circ} \mathrm{C}$, cell sheets were fed with the medium containing one-tenth concentration of lactoalbumin hydrolysate and incubated at $39^{\circ} \mathrm{C}$ for 5 hours. The same medium containing ${ }^{14} \mathrm{C}$-amino acids mixture was added to each tube, and tunicamycin-treatment was started at the same time. At 12 hour of treatment at $39^{\circ} \mathrm{C}$, cell cultures were fractionated according to the method shown in Fig. 8 . Three tubes were used for each determination.

fractions. Incorporation into the membrane fraction was affected to a lesser extent than the other fractions. NDV is known to mature at the surface membrane and obtains its envelope from the plasma membrane during budding from it. ${ }^{6)}$ Altered membrane synthesis is induced by other viruses. ${ }^{7 \sim 10}$ ) The resistance of membrane protein synthesis in the presence of tunicamycin in NDV-infected CEF suggests some relation with these obșervations.

\section{Effect on Choline} Incorporation

Fig. 9. Fractionation of cultures of CEF labeled with ${ }^{14} \mathrm{C}$-amino acids for determination of effect of tunicamycin on protein synthesis.

Whole culture in test tube

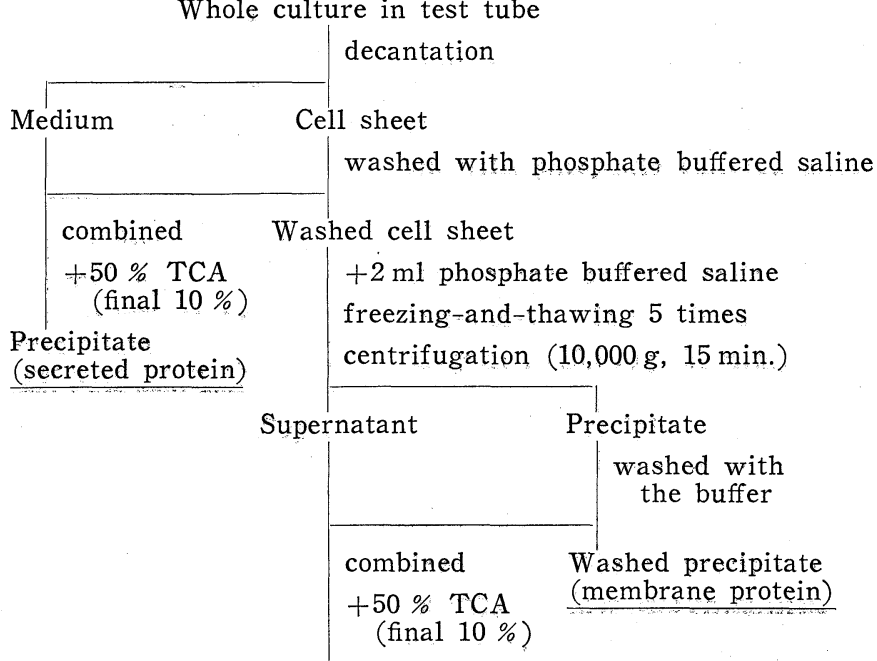

Precipitate

(cytoplasmic protein)

Choline is a lipid abundantly found in the plasma membranes of animal cells. ${ }^{11)}$ In contrast to amino acid incorporation, choline uptake was stimulated after infection with NDV (Fig. 10). Tunicamycin present in concentrations up to $1.0 \mu \mathrm{g} / \mathrm{ml}$ had no effect at all on the incorporation.

\section{Effect on Sugar Incorporation}

Glucosamine is known to be incorporated only into the membrane fraction and 
without modification in $\mathrm{HeLa}$ cells ${ }^{12)}$ and the same may be presumed with CEF. Similar to choline uptake incorporation of glucosamine into acidinsoluble product was stimulated after infection with NDV (Fig. 11). Treatment with tunicamycin significantly inhibited the incorporation. Glucosamine uptake was more sensitive to the antibiotic in NDV-infected cells than in mock-infected cells, $i$. e., the inhibition ratios were 22,44 and $53 \%$ in mockinfected cells (Fig. $11 \mathrm{~A}$ ) and 28, 61 and $87 \%$ in NDVinfected cells (Fig. $11 \mathrm{~B}$ ) at antibiotic concentrations of $0.25,0.5$ and $1.0 \mu \mathrm{g} / \mathrm{ml}$, respectively.

When ${ }^{14} \mathrm{C}$-glucosaminelabeled cells were filtered after freezing-and-thawing without treatment with TCA, it was found that incorporation of glucosamine was inhibited more extensively (72\% inhibition at $0.5 \mu \mathrm{g} / \mathrm{ml}$ ) than observed with whole cells (Fig. $12 \mathrm{~A})$.

A similar inhibitory effect of tunicamycin was observed during the incorporation of ${ }^{14} \mathrm{C}$-glucose (Fig. $12 \mathrm{~B}$ ).

\section{Discussion}

Tunicamycin exerted negligible effects on the incorporation of ${ }^{14} \mathrm{C}$-uridine (Fig. 2), ${ }^{3} \mathrm{H}-$ thymidine (Fig. 7), ${ }^{14} \mathrm{C}$-choline (Fig. 10) and ${ }^{14} \mathrm{C}$-amino acids (Fig. 8), but it significantly
Fig. 10 Effect of tunicamycin on incorporation of choline into membrane fraction.

Cell sheets of CEF in test tubes ( $1 \mathrm{ml} /$ tube) were infected (10 PFU/ cell) or mock-infected with NDV. ${ }^{14} \mathrm{C}$-Choline chloride $\left(\begin{array}{lll}0 & 1 \mu \mathrm{Ci} / \mathrm{ml})\end{array}\right.$ was added at 4 hour after the infection, and tunicamycin treatment was started at the same time. At designated time intervals duplicate samples were chilled in an ice-water bath After freezing-and-thawing four times destructed cultures were filtered and membrane fraction was collected on Millipore filters. Radioactivity on the filters was counted as described in Materials and Methods

A Mock infected

B. NDV infected
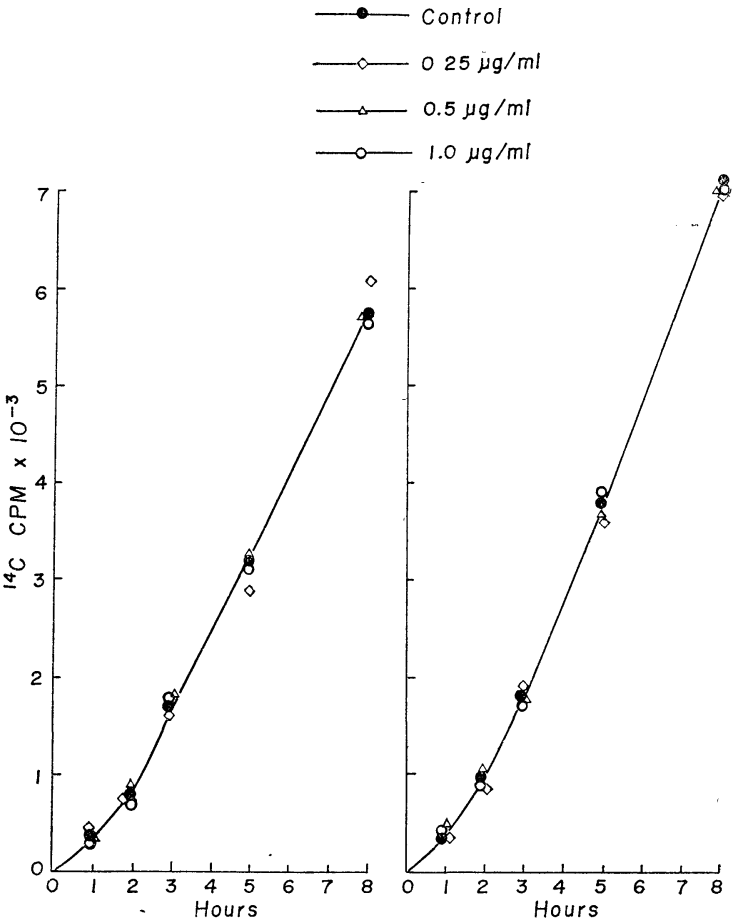

Fig. 11. Effect of tunicamycine on incorporation of glucosamine into acid-insoluble product.

Cultures of $\mathrm{CEF}$ in test tubes ( $1 \mathrm{ml} /$ tube) were infected (10 PFU/ cel1) or mock-infected with NDV, and ${ }^{14} \mathrm{C}$-glucosamine $(025 \mu \mathrm{Ci} / \mathrm{ml})$. was added at 4 hour after the infection. Tunicamycin was added at the same time with the radioactive glucosamine. Acid-insoluble radioactivity was counted after destruction of cell sheets by freezingand-thawing four times

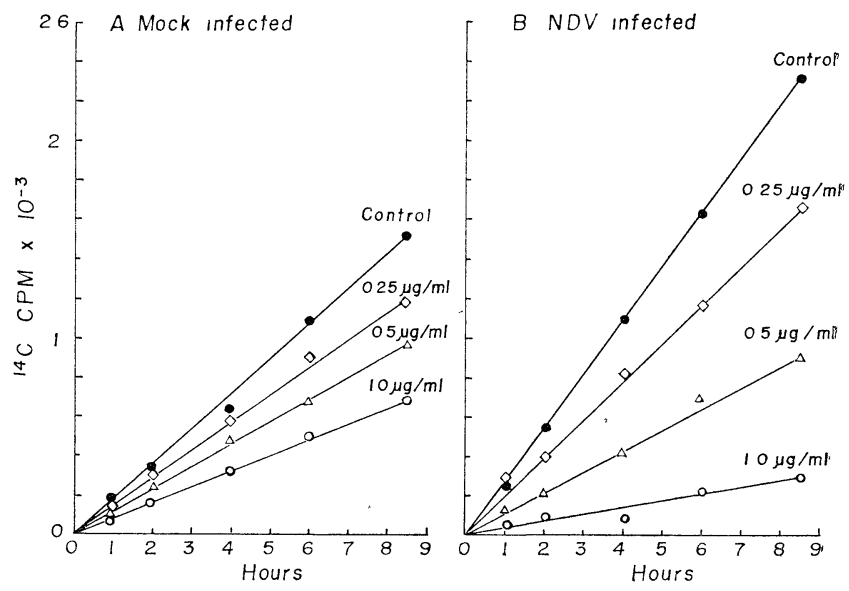


inhibited the uptake of glucosamine and glucose (Fig. 12). A similar effect of the antibiotic was observed with Bacillus subtilis. ${ }^{4)}$ Tunicamycin was found to induce various morphological changes of gram-positive bacteria and yeasts. ${ }^{4}$ The results obtained with animal and microbial cells suggest that similar tunicamycinsensitive processes of cell envelope synthesis take place in both types of cells. Reversal of the antiviral activity of tunicamycin by some aminosugar derivatives ${ }^{3)}$ suggests that the sensitive step is somehow associated with glycosidation.

NDV is known to mature at the cell surface and some components of the virus particle are synthesized there. ${ }^{6}$ ) The stimulated incorporation of choline and glucosamine after infection with NDV (Figs. 10 and 11) might be related with the characteristic maturation process of the virus.

Glycoproteins have attracted interest lately in relation to virus multiplication, ${ }^{7,8}$ malignant transformation ${ }^{13 \sim 15)}$ and synthesis of secretion proteins ${ }^{16)}$. Appropriate inhibitors of such events are rare at present, and tunicamycin might become a useful tool in such investigations.

\section{Acknowledgement}

This investigation was financially supported by grant-in-aid from Tokyo Biochemical Research Foundation, Kaiun Mishima Memorial Funds and Waksman Foundation of Japan.

\section{References}

1) Takatsuki, A.; K. Arima \& G. Tamura: Tunicamycin, a new antibiotic. I. Isolation and characterization. J. Antibiotics $24: 215 \sim 223,1971$

2) Takatsuki, A. \& G. Tamura: Tunicamycin, a new antibiotic. II. Some biological properties of the antiviral activity of tunicamycin. J. Antibiotics $24: 224 \sim 231,1971$

3) Takatsuki, A. \& G. Tamura: Tunicamycin, a new antibiotic. III. Reversal of the antiviral activity of tunicamycin by aminosugars and their derivatives. J. Antibiotics $24: 232 \sim 238,1971$

4) Takatsuki, A.; K. Shimizu \& G. Tamura: Effect on tunicamycin on microorganisms: Morphological changes and degradation of RNA and DNA induced by tunicamycin. J. Antibiotics, in press

5) Takatsuki, A.; G. Tamura \& K. Arima: Mode of action of xanthocillin $\mathrm{X}$ monomethylether on multiplication of Newcastle disease virus in cultured cells. J. Antibiotics $22: 151 \sim 160,1969$

6) Scholtissek, C.; R. Drzeniek \& R. Rott; Myxoviruses, in "The Biochemistry of Viruses" (H. B. Levy, ed.), Marcel Dekker, 1969

7) Keller, J. M.; P. G. Spear \& B. Roizman: Proteins specified by herpes simplex virus. III. Viruses differing in their effect on the social behavior of infected cells specify different membrane glycoproteins. Proc. Nat. Acad. Sci. 65 : 865 871, 1970 
8) Burge, B, W. \& J. H. Strauss, Jr.: Glycopeptides of the membrane glycoprotein of Sindbis virus. J. Mol. Biol. $47: 449 \sim 466,1970$

9) Holland, J. J. \& E. D. Kiehn: Influenza virus effects on cell membrane protein. Science 167 : $202 \sim 205,1970$

10) Aghadashi, M. \& E. Gold: Origin of herpes simplex virus envelope. Bacteriol. Proc. 1970 : 162,1970

11) Lennarz, W. J.: Lipid metabolism. Ann. Rev. Biochem. $39: 359 \sim 388,1970$.

12) Reith, A.; R. Ofтebro \& R. Seljelid: Incorporation of ${ }^{3} \mathrm{H}$-glucosamine in HeLa cells as revealed by light and electron microscopic autoradiography. Exptl. Cell Res. 59 : 167 170, 1970

13) Burger, M. M. \& A. R. Goldberg: Identification of a tumor-specific determinant on neoplastic cell surfaces. Proc. Nat. Acad. Sci. $57: 359 \sim 366,1967$

14) Meezan, E.; H. C. Wu, P. H. Black \& P. W. Robbins: Comparative studies on the carbohydratecontaining membrane components of normal and virus-transformed mouse fibroblasts. II. Separation of glycoproteins and glycopeptides by Sephadex chromatography. Biochemistry 8 : 2518 2524, 1969

15) Molnar, J.: Glycoproteins of EHRLICH ascites carcinoma cells. Incorporation of $\left[{ }^{14} \mathrm{C}\right] \mathrm{gluco}$ samine and $\left[{ }^{14} \mathrm{C}\right]$ sialic acid into membrane proteins. Biochemistry $6: 3064 \sim 3076,1967$

16) EYLAR, E. H.: On the biological role of glycoproteins. J. Theoret. Biol. $10: 89 \sim 113,1966$ 